\title{
Effect of prey abundance and size on the growth and survival of larval fish: an experimental study employing large volume enclosures
}

\author{
K. T. Frank ${ }^{1} \&$ W. C. Leggett ${ }^{2}$ \\ ${ }^{1}$ Department of Fisheries \& Oceans, Marine Ecology Laboratory, Bedford Institute of Oceanography, Dartmouth, Nova Scotia \\ B2Y 4A2, Canada \\ ${ }^{2}$ Department of Biology, McGill University, 1205 Dr. Penfield Ave., Montreal H3A 1B1, Canada
}

\begin{abstract}
We examined the effect of natural variations in the concentration and size composition of plankton in coastal waters on the growth and survival of recently hatched larval capelin Mallotus villosus. Known numbers of larvae were stocked into $4 \mathrm{~m}^{3}$ in situ enclosures, containing plankton communities whose size composition and total particle concentration mirrored those occurring naturally during times when the nearshore waters were alternately dominated by deep upwelled waters, and by warmer surface waters. Daily growth of larvae was unrelated to total plankton concentration, but strongly correlated with the concentration of plankton in the 40 to $51 \mu \mathrm{m}$ (esd) size range. Daily mortality was negatively correlated with concentrations of plankton $<81 \mu \mathrm{m}$ (esd). This correlation was strongest with prey in the 32 to $40 \mu \mathrm{m}$ and 40 to $51 \mu \mathrm{m}$ (esd) size classes. The in situ concentration of plankton in the optimum size range for growth and survival was temporally dynamic and strongly influenced by wind-driven water mass exchange. The relevance of these findings to previous studies of the effect of prey concentration on growth and survival in larval fishes is discussed.
\end{abstract}

\section{INTRODUCTION}

Food quality and quantity are widely hypothesized to be the primary determinants of the growth and survival of marine fish larvae. General support for this viewpoint has been derived from both laboratory (Lasker et al. 1970, Parsons \& LeBrasseur 1970, Wyatt 1972, Houde 1975, Werner \& Blaxter 1981) and field studies (Corlett 1958, Sysoevea \& Degtereva 1965, Steele et al. 1969, Lasker 1975, Dekhnik \& Sinyvkova 1976, Lasker \& Zweifel 1978). Food conditions at the onset of exogenous feeding are hypothesized to be especially important. This has frequently been demonstrated in the laboratory, but field verification has been difficult to achieve (see reviews in May 1974, Leggett 1986). The links between in situ food quantity and quality and survival remain obscure.

Most first-feeding fish larvae consume microzooplankton in the 30 to $200 \mu \mathrm{m}$ size range (Arthur 1977. Theilacker \& Dorsey 1980, Hunter 1981). This group generally includes (1) protozoans in the families Foraminifera, Radiolaria, Tintinnidae and Ciliata other than tintinnids, and (2) metazoans such as the naupliar and post-naupliar stages of Copepoda, Heteropoda and Pteropoda (Beers \& Stewart 1967). Quantitative sampling of microzooplankton requires mesh sizes of plankton nets much smaller than those commonly used in studies involving larval fishes.

The food resource available to first-feeding larvae is believed to depend on the combined influence of the size distribution of the plankton community of which the larvae are a part, its nutritional value, and its concentration. These characteristics of the food base can vary over short distances $(0.1$ to $10 \mathrm{~m}$; see Owen 1981 ) and brief time scales (approximately $6 \mathrm{~h}$; Frank \& Leggett $1982 b$, Fortier \& Leggett 1984, Govoni et al. 1985, Courtois \& Dodson 1986) in response to local hydrographic conditions. The importance of such microscale heterogeneity in prey availability to larval survival has not been well studied, but early indications are that it may be significant (Fortier \& Leggett 1984, 1985, Taggart 1986). The combined effect of sampling with coarse mesh nets and the significant small scale variability in the distribution of microzoo- 
plankton could be a major reason for the absence of a clear definition of the in situ relations between food availability, growth and survival.

The potential importance of physical oceanographic features that produce broadscale changes in prey availability is somewhat more obvious. Seasonal and spatial differences in water mass characteristics (e.g. temperature) have been shown to influence zooplankton particle size spectra (Deevey 1960, Beers \& Stewart 1967. Arthur 1977, Ware 1977. Tremblay \& Roff 1983). Such changes, when coupled with advective processes, may result in asynchronous distributions of larvae and their principle prey (Nelson et al. 1977, Lasker 1978, Bailey 1981). Persistent turbulence may also influence zooplankton species composition and food chain length (Greve \& Parsons 1977, Landry 1977) and turbulent events (e.g. storms) may dilute aggregations of microzooplankton (Lasker 1978, Lough 1984, Tilseth \& Ellertsen 1984). These dynamic interactions have been hypothesized to significantly influence larval survival and recruitment, but direct evidence of this effect is wanting.

Research on inshore, eastern Newfoundland waters indicates the existence of dramatic, rapid, and repeated transitions from plankton communities characteristic of coastal waters to those characteristic of deeper waters in response to changes in wind conditions (Frank \& Leggett 1982b, Taggart 1986). Winddriven water mass replacements in these coastal embayments occurs synchronously over approximately $700 \mathrm{~km}$ of coastline at a mean frequency of $3.5 \mathrm{~d}$ (range: 1 to 13 d; Frank \& Leggett 1982a, Leggett et al. 1984, Frank \& Leggett 1985). Offshore (SW) winds, the predominant summer wind condition for the region, result in upwelling of the deep, cold, oceanic water mass surrounding Newfoundland. During onshore (NE) winds, the warmer surface waters are advected into the nearshore. These surface waters are characterized by high concentrations of small plankton, relative to the deep upwelling waters. Larval fish, particularly capelin Mallotus villosus, abound in this nearshore region. Capelin larvae originate from adhesive eggs positioned intertidally on beaches at the heads of coastal embayments. The larvae actively emerge in synchrony from their spawning beaches in distinct pulses during infrequent onshore winds (Frank \& Leggett 1981, 1983b). Because larvae accumulate in the sediments during the intervals between infrequent onshore winds the densities of newly emergent capelin larvae in the water column often reach or exceed $1000 \mathrm{~m}^{-3}$ (Frank \& Leggett 1981, Taggart 1986). The numbers of newly hatched larvae of other demersal spawners, notably winter flounder $P_{\text {seudopleuronectes }}$ americanus, radiated shanny Ulvaria subbifurcata and sea snails Liparis spp, also increased dramatically during the occurrence of food-rich surface waters in the nearshore during onshore winds. These changes, too, appear to result from active responses to water mass exchange (Frank \& Leggett 1983a). The timing of these larval emergences, relative to changes in the microzooplankton community induced by hydrographic conditions, has been hypothesized to be a significant regulator of survival in these species (Frank \& Leggett 1983a). In this paper we examine the extent to which hydrographic conditions, as moderated by meteorological events, influence the abundance and size structure of the plankton community in the nearshore waters of eastern Newfoundland, and the effects of these changes in the plankton community on the in situ growth and survival of capelin larvae.

\section{MATERIALS AND METHODS}

The study was conducted during the summer of 1981 at Bryant's Cove $\left(47^{\circ} 40.5^{\prime} \mathrm{N}, 53^{\circ} 11.0^{\prime} \mathrm{W}\right)$, a major spawning site for capelin in Conception Bay, Newfoundland. Further details of the study site are provided in Frank \& Leggett $(1981,1982 b)$.

In situ feeding experiments, designed to address the relation between food quantity and quality and larval growth, were conducted in enclosures. The enclosures consisted of $1 \mathrm{~m}$ diameter $\times 5 \mathrm{~m}$ long cylindrical plankton nets (mesh size $<5 \mu \mathrm{m}$ ) supported vertically in the water column from wooden floats. Four steel hoops spaced at $1 \mathrm{~m}$ intervals along the nets provided support against collapse. The bottom meter of the net was tapered and a PVC cod end was attached. The wooden box frame float, through which the net was suspended, maintained the mouth of the net at least $50 \mathrm{~cm}$ above the water surface. The enclosures were moored in the nearshore waters of Bryant's Cove (depth $=7 \mathrm{~m}$ ) adjacent to the capelin spawning beach.

Six enclosures were used for Experiment I (11 to 22 July). Three enclosures were used during Experiment II (22 to $31 \mathrm{July}$ ). Immediately prior to the start of each experiment, the enclosures were installed on their floats and filled with filtered (10 um) seawater. Each enclosure was stocked with 1000 capelin larvae collected directly from the spawning beach. At least 50 larvae collected at the same time as those used for stocking were measured to determine the size and physical condition of larvae stocked into the enclosures. Handling mortality of capelin larvae used for stocking the enclosures averages less than $2 \% 1 \mathrm{~d}$ after collection from the spawning beach (DeLaFontaine, McGill University, unpubl. data). Plankton food was added to randomly assigned enclosures in varying concentrations. Food levels were established by towing a $13 \mathrm{~cm}$ diameter, $10 \mathrm{um}$ mesh bongo net at low 
speeds over one of 3 measured distances $(50 \mathrm{~m}, 200 \mathrm{~m}$ $400 \mathrm{~m}$ ) in the cove. The contents of each net was washed thoroughly through a $355 \mu \mathrm{m}$ sieve and the retained $(>355 \mu \mathrm{m}$ ) size fraction was discarded to preclude stocking of potential predators into the enclosures. The $<355 \mu \mathrm{m}$ size fraction from one of the paired bongo samples was preserved immediately for subsequent determination of the quantity and size distribution of food added to each enclosure. The second was added to the assigned enclosure. Food additions were made at the initiation of the experiment, and at $3 \mathrm{~d}$ intervals thereafter. Each enclosure was treated with plankton food collected from one of the 3 tow distances as shown in Table 1.

Table 1. Treatment of enclosures with food from 50, 200 and $400 \mathrm{~m}$ tows

\begin{tabular}{|cccccccccc|}
\hline & \multicolumn{10}{c|}{ Enclosure No. } \\
& 1 & 2 & 3 & 4 & 5 & 6 & 7 & 8 \\
\hline Exp. I & 400 & 400 & 50 & 50 & 200 & 200 & - & - \\
Exp. II & - & 200 & - & - & - & - & 400 & 200 \\
\hline
\end{tabular}

Food collections were made during both onshore and offshore wind conditions. This pattern of enclosure stocking resulted in significant differences in total plankton concentrations between enclosures, and in plankton size composition between experiments. Because of the different number of enclosures available for use between experiments we consistently maintained 8 tows per sampling interval to describe the temporal dynamics of microzooplankton in the cove.

We used a PAR model 36975 self-priming diaphram pump daily to collect dead capelin larvae lost from the water column by sedimentation, from the enclosure cod ends. Field tests showed that capelin larvae settled out of the water column 2 to $3 \mathrm{~h}$ after dying, recovery rates of larvae generally exceeded $95 \%$ of the initial number of stocked larvae after $3.5 \mathrm{~d}$, and dead larvae remained intact and in good condition for several days after death at the temperatures experienced during our experiments (DeLaFontaine, McGill University, unpubl. data). Growth rate estimates of capelin larvae in the enclosures were based on total length measurements of larvae collected with a $13 \mathrm{~cm}$ diameter net (153 $\mu \mathrm{m}$ mesh) hauled vertically from the bottom to the surface of each enclosure. A model TA II Coulter Counter was used to size and enumerate the plankton from the preserved half of the paired bongo tow. We counted 12 particle size classes (equivalent spherical diameter, esd: 25 to 32,32 to 40,40 to 51,51 to 64,64 to 81,81 to 102,102 to 128,128 to 161,161 to 203,203 to 256,256 to 323,323 to $406 \mu \mathrm{m}$ ).

\section{RESULTS}

\section{Hydrographic conditions}

The summer water temperatures in Bryant's Cove exhibit temporal oscillations linked to wind-driven water mass replacement (Frank \& Leggett 1982b). During the period of this study the correlation between the daily mean water temperature and the prevailing wind conditions (defined as $\sin ^{-1}$ [h of onshore wind $\left.\mathrm{d}^{-1} 24^{-1} \mathrm{~J}^{0.5}\right)$ was $\mathrm{r}=0.72(\mathrm{P}<0.05)$ indicating that coastal water mass exchange (Frank \& Leggett 1982b, Taggart 1986) occurred during this period.

\section{Plankton size structure}

Two time-independent particle-size spectra were evident in the nearshore waters of Bryant's Cove. One type, which prevailed only during onshore wind conditions, was strongly skewed towards the lower end of the size spectrum with a pronounced peak at the 40 to $51 \mu \mathrm{m}$ (esd) size interval. This peak contained, on average, $20 \%$ of all the particles sampled between 25 and $323 \mu \mathrm{m}$ (esd) in the surface waters (Fig. 1). The second type of size spectrum was broadly bell shaped, persisted only during offshore wind conditions, and peaked at the 81 to $102 \mu \mathrm{m}$ (esd) size interval. The relative proportion of particles in this interval averaged $15 \%$ (Fig. 1). A comparison of all size intervals between the 2 spectra revealed significant differences $(\mathrm{P}<0.01)$ in the relative proportion of particles in 9 of the 12 size intervals.

\section{Plankton concentrations}

The total particle concentration in 72 plankton collections taken from the Cove varied from 22 to 945 particles $1^{-1}$. The range of the mean particle concentration over 9 sampling dates was 55 to 489 particles $\mathrm{l}^{-1}$. Particle concentration was lower, and less variable, in collections made during offshore wind conditions (mean $=142 \mathrm{l}^{-1}, \mathrm{CV}=15 \%$ ) as compared to those taken during onshore winds (mean $=209 \mathrm{l}^{-1}$, $\mathrm{CV}=82 \%$ ). Fifty $\%$ of the variation in total particle concentration in the cove was explained by the prevailing wind conditions. The equation describing this relation was:

$$
\mathrm{Y}=73.9+4.13 \mathrm{~W}, \mathrm{n}=9, \mathrm{P}<0.01
$$

where $\mathrm{W}=\arcsin \left(\mathrm{h} \text { of onshore wind } \mathrm{d}^{-1} 24^{-1}\right)^{0.5} ; \mathrm{Y}=$ total particle concentration in no. $1^{-1}$. Maximum particle concentrations were coincident with persistent onshore wind conditions $\left(>18 \mathrm{~h} \mathrm{~d}^{-1}\right)$ which resulted in 


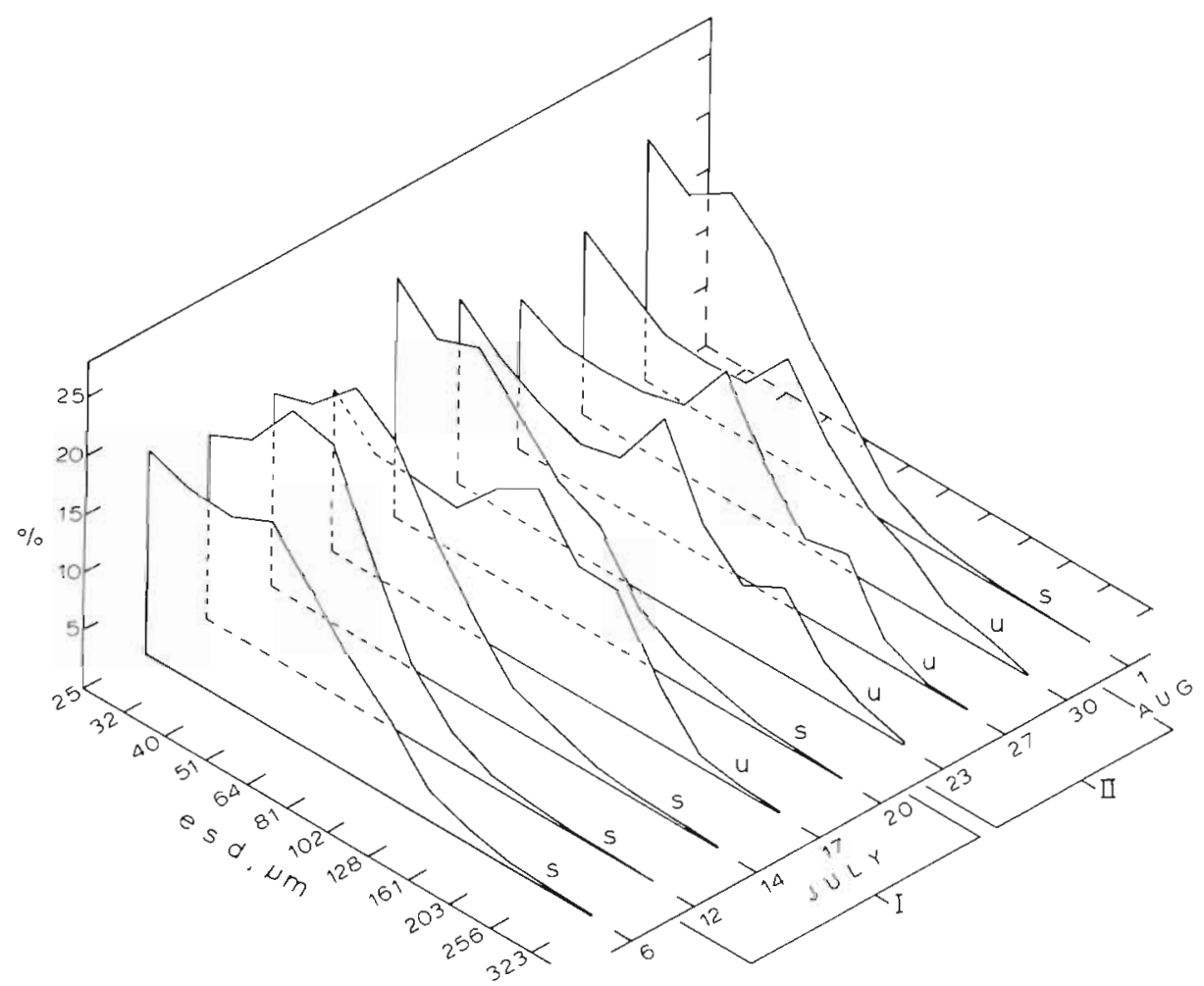

Fig. 1. Particle size spectra in coastal Newfoundland during surface water mass (s) and upwelled water mass (u) intrusions. Values in each size interval are means of replicate tows $(n=8)$ for each sampling date, expressed as percentages of total particle concentration. I and II indicate times of enclosure experiments

complete replacement of the upwelled water mass by surface waters.

The concentration of particles in the various size intervals over the 9 sampling dates is depicted in Fig. 2. In samples collected during each of the 4 offshore wind conditions sampled, the concentration of particles in each size interval was essentially identical. During onshore wind conditions, the quantity of particles $1^{-1}$ in the 40 to $51 \mu \mathrm{m}$ size interval varied by as much as an order of magnitude (Fig. 2). The high concentration of small particles $(<81 \mu \mathrm{m})$ relative to larger particles $(>81 \mu \mathrm{m})$ was a striking feature of collections made during onshore winds, the ratio of the 2 size categories (small:large) averaging approximately $7: 1$. During offshore wind conditions (upwelling) this ratio was only slightly $>1: 1$. A correlation analysis showed the number of particles $1^{-1}$ in all size classes $<81 \mu \mathrm{m}$ (esd) to be significantly and positively correlated with one another and each was significantly and negatively correlated with the no. $\mathrm{I}^{-1}$ in each size class $>81 \mu \mathrm{m}(\mathrm{p}<0.05)$.

\section{Physical regulation of prey size spectra and abundance}

The pattern of particle size variation, both in terms of relative and absolute levels of abundance, was determined largely by the prevailing wind condition (range of $r^{2}: 44$ to $89 \%$; Fig. 3). Abundance and percent of particles in the size classes $<81 \mu \mathrm{m}$ were all positively correlated with $\mathrm{W}$. Conversely, all of the particle size intervals $>81 \mu \mathrm{m}$ were negatively associated with $W$ (Fig. 3). Thus, a major portion of the variability in the particle size spectrum of the nearshore plankton community was explained by wind-induced advection of discrete water masses into the cove.

\section{Conditions experienced by larvae in the enclosures}

The fundamental differences in prey particle size and abundance occurring in Bryant's Cove, and throughout coastal Newfoundland (Leggett et al. 1984), in response to wind-forced water mass exchange, were recreated in our enclosures by stocking with plankton collected during onshore and offshore winds. During Experiment I ( 12 to 20 July), 3 of 4 plankton collections/additions were made during onshore wind conditions. During Experiment II (22 to 30 July) all (3) plankton collections/additions were made during offshore wind conditions (Fig. 1). As a result of these manipulations, larvae reared during Experiment $I$ were exposed to a smaller overall preysize spectra (peak at approximately 40 to $50 \mu \mathrm{m}$ ) than those reared during Experiment II (Fig. 1). The total prey concentration experienced by the larvae and the concentration of prey in the $<81 \mu \mathrm{m}$ size class were also greatest during Experiment I (Table 2).

Differences in tow lengths during plankton collec- 
Fig. 2. Spectra of particle density in the surface (s) and upwelled (u) water mass in coastal Newfoundland. Values in each size interval represent means of replicate tows $(\mathrm{n}=8)$ for each sampling date. I and II indicate times of enclosure experiments

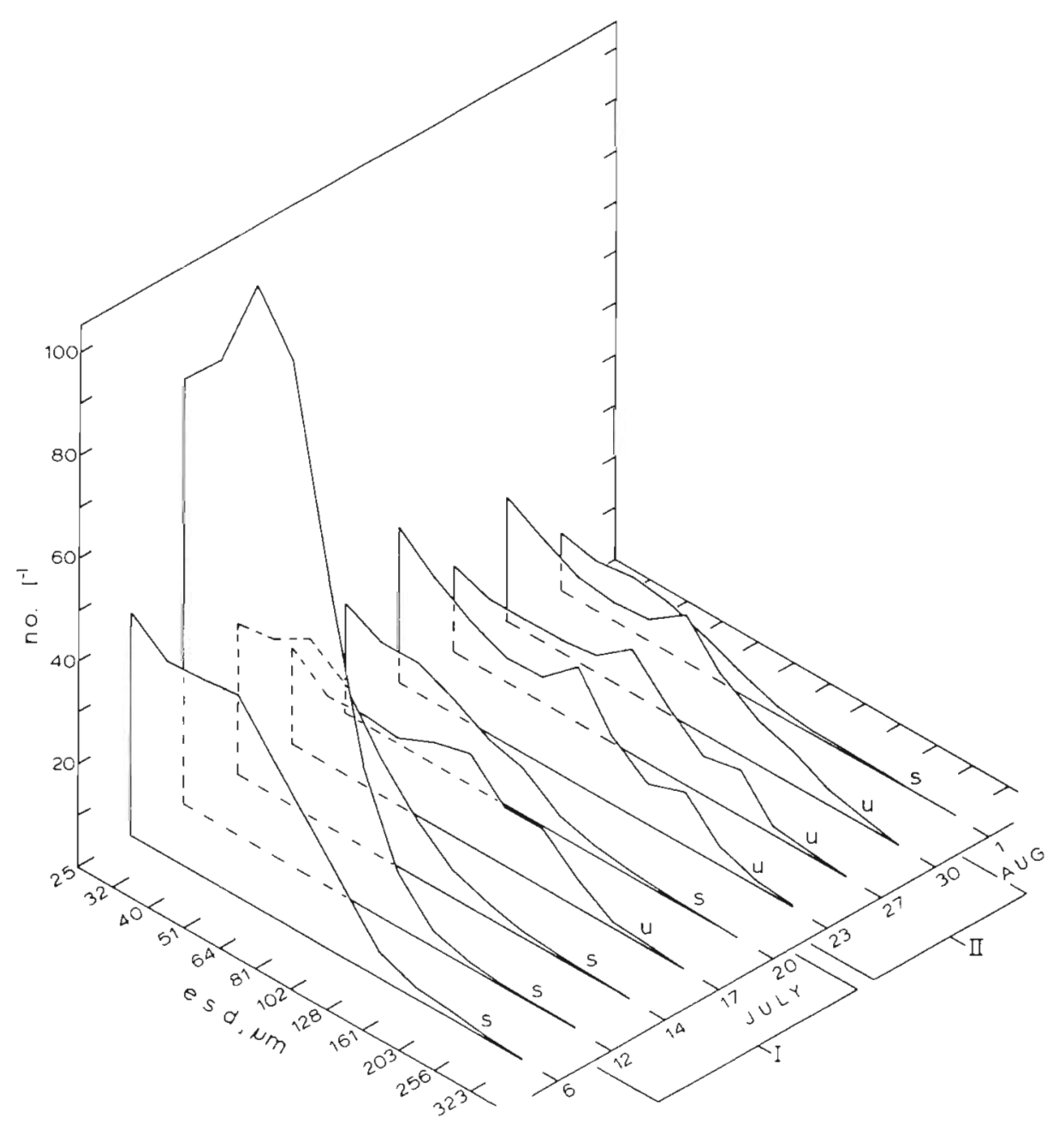

tions produced significant differences in the total abundance of prey in each enclosure but not by a factor equivalent to the difference in the volume of water filtered between the 3 towing distances (Table 2). Plankton patchiness, commonly encountered in the cove waters (see previous section, 'Plankton concentrations'; also Taggart \& Leggett [1984] showed that replicate net and pump sampling [average volume filtered $=37$ and $2.5 \mathrm{~m}^{3}$ respectively] of copepods on one July day in each of 3 yr in Bryant's Cove yielded CV's ranging from 30 to $119 \%$ ), is believed to be responsible for this result. Nonetheless, a strong correlation $(r>0.95)$ existed between tow duration and the average total prey concentration established in the different enclosures within each experiment. During Experiment I the resulting average prey densities in the 6 enclosures ranged from 69 to 118 particles $I^{-1}$. During Experiment II densities ranged from 79 to 83 particles $1^{-1}$ (Table 2 ). The range of total prey abundances in each enclosure (Table 2) were approximately equal to the abundance of particles $<355 \mu \mathrm{m}$ occurring in situ (see Fig. 2 where the range of the mean particle concentration over 9 sampling dates was 55 to 489 particles $\mathrm{l}^{-1}$ ).

Recent experiments have shown that temperature and salinity changes in situ are accurately reflected inside enclosures of the design we employed with a time lag of less than $3 \mathrm{~h}$, whereas the biological characteristics within an enclosure remained unchanged and isolated from the surrounding waters (DeLaFontaine, McGill University, unpubl. data). These experiments also showed that the diel patterns of vertical distribution of capelin larvae and of plankton in such enclosures mirror those occurring in situ. Average water temperatures during Experiments I and II were very similar (Exp. I, $5.7^{\circ} \mathrm{C}, \mathrm{SD} 2.09$; Exp. II, $6.4^{\circ} \mathrm{C}, \mathrm{SD} 1.06$ ).

\section{Larval growth}

We estimated growth rate as the difference between the average size of larvae at the initiation and termination of each experiment, divided by the elapsed time. 
The average growth rate of capelin larvae reared during Experiment I was $0.23 \mathrm{~mm} \mathrm{~d}^{-1}$ (range of means among enclosures: 0.18 to $0.25 \mathrm{~mm} \mathrm{~d}^{-1}$; range of $\mathrm{CV}$ : 12 to $41 \%$ ). Larval growth rates during Experiment II averaged $0.16 \mathrm{~mm} \mathrm{~d}^{-1}$ (range of means among enclosures: 0.13 to $0.18 \mathrm{~mm} \mathrm{~d}^{-1}$; range of $\mathrm{CV}: 22$ to $36 \%$ ), approximately $30 \%$ lower on average than the growth rates observed during Experiment I (Table 2). These growth differences were not systematically related to differences in the total quantity of food available to the larvae $(\mathrm{r}=0.29, \mathrm{P}>0.05)$. Growth rates were, however, significantly and positively related to the concentration of food in the 40 to $51 \mu \mathrm{m}$ (esd) size interval $(\mathrm{r}=0.72, \mathrm{P}<0.05$; Fig. 4A). Growth rate was also positively, but non-significantly, related to the concentration of prey in the 25 to 32,32 to 40,51 to 64 and 64 to $81 \mu \mathrm{m}$ (esd) size classes. A plot of the correlation coefficient ' $r$ ' $v$ s food size class revealed a dome shaped function (Fig. 4B), suggesting an optimum prey size at 40 to $51 \mathrm{um}$ (esd). At food sizes $>81 \mu \mathrm{m}$ (esd) all correlations were negative. Correlation coefficients derived from all possible combinations of particle size groups $<81 \mu \mathrm{m}$ and growth rate were positive, but non-significant.

\section{Larval mortality rates}

The daily mortality rates of larval capelin, estimated from the daily sampling of dead larvae from the enclosure cod ends, were significantly lower during Experiment I (mean $=2.3 \% \mathrm{~d}^{-1}, 95 \%$ confidence interval: 1.6 to 3.0 ) relative to Experiment II (mean $=$ $7.4 \% \mathrm{~d}^{-1}, 95 \%$ confidence interval: 4.8 to 9.9$)$. Daily mortality, averaged over the duration of the experimental period, was significantly negatively correlated with the concentration of prey particles in each of the prey size classes 25 to 32,32 to 40,40 to 51 and 51 to $60 \mu \mathrm{m}$ (esd). The relation between daily mortality and prey concentration in the 40 to $51 \mu \mathrm{m}$ (esd) size class is shown in Fig. 5A. The plot of ' $\mathrm{r}$ ' vs daily mortality revealed a concave function with the strength of the negative correlation between daily mortality and prey size being greatest at the 32 to 40 and 40 to $51 \mu \mathrm{m}$ (esd) size classes (Fig. 5B). For all size classes $>64$ to $81 \mu \mathrm{m}$ the correlation was positive. This latter result derives primarily from the negative correlation between particles $l^{-1}$ in size classes $<81 \mu \mathrm{m}$ and those $>81 \mu \mathrm{m}$ (esd).

\section{DISCUSSION}

To date, knowledge of the importance of the abundance and size distribution of planktonic prey to the in situ growth and survival of larval fishes has been both

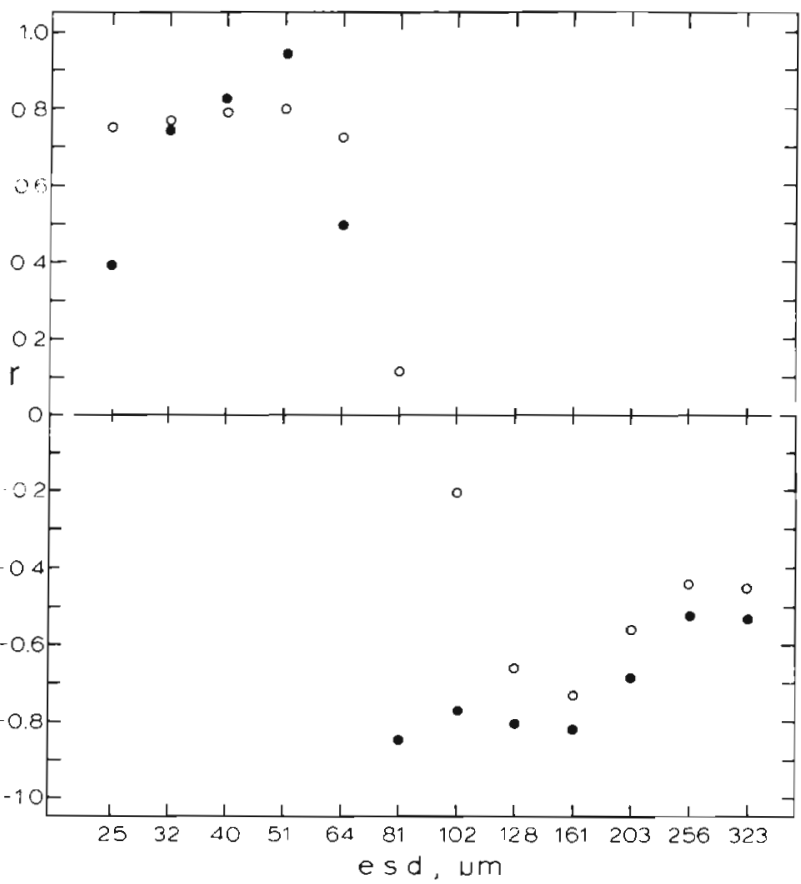

Fig. 3. Correlation coefficients $(\mathrm{r})$ resulting from the regression of particle concentration $(O)$ and percentage of particles (•) in each of 12 microzooplankton size classes on the daily duration of onshore winds $(p<0.05$ for $r=0.67$ and $p<0.01$ for $\mathrm{r}=0.80, \mathrm{df}=7$ )

limited and largely circumstantial (Leggett 1986). Several studies have yielded data which tend to discount the importance of food abundance as a determinant of early larval survival and recruitment in marine fishes. However, without exception, these studies have considered only total food biomass, without reference to size spectrum (O'Boyle et al. 1984, Sinclair \& Iles 1985 , Sinclair et al. 1985).

The results of the experiments reported here indicate that the size structure of the planktonic community to which larval fish are exposed can dramatically influence both their growth and survival, and that this influence can override the importance of total plankton abundance at intermediate food levels. This conclusion is supported by the results of both the growth and the survival analyses.

\section{Growth}

The range of absolute densities of plankton to which larvae were exposed in Experiments I and II were similar (69 to 118 and 79 to $83 \mathrm{l}^{-1}$ respectively). The minimum total prey concentrations were approximately 10 to 50 times higher than estimates of the minimum levels required to support growth and survival of the larvae of several species of marine fishes in a variety of experimental enclosures (1 to 10 parti- 
Table 2. Average concentration (no. $^{-1}$ ) of particles 25 to $406 \mu \mathrm{m}$ (esd) experienced by capelin larvae in each enclosure during Experiments I and II. Range of particle concentration is in parentheses. Larval growth ( $\left.\mathrm{mm} \mathrm{d}^{-1}\right)$ and mortality $\left(\% \mathrm{~d}^{-1}\right)$ responses to each feeding condition are also shown

\begin{tabular}{|c|c|c|c|c|c|c|c|c|c|}
\hline \multirow{2}{*}{$\begin{array}{c}\text { Particle size } \\
\text { range (esd; } \mu \mathrm{m} \text { ) }\end{array}$} & \multicolumn{9}{|c|}{ Experiment/Enclosure } \\
\hline & $\mathrm{I} / 1$ & $1 / 2$ & $1 / 3$ & {$[/ 4$} & $1 / 5$ & I/6 & {$[1 / 2$} & $\mathrm{II} / 7$ & II $/ 8$ \\
\hline $25-32$ & $\begin{array}{c}17.20 \\
(5.2-40.3)\end{array}$ & $\begin{array}{c}16.95 \\
(9.0-39.5)\end{array}$ & $\begin{array}{c}15.55 \\
(6.0-31.4)\end{array}$ & $\begin{array}{c}13.82 \\
(6.7-30.4)\end{array}$ & $\begin{array}{c}14.70 \\
(6.5-28.5)\end{array}$ & $\begin{array}{c}15.77 \\
(5.8-32.2)\end{array}$ & $\begin{array}{c}11.07 \\
(6.7-15.7)\end{array}$ & $\begin{array}{c}11.87 \\
(7.4-14.4)\end{array}$ & $\begin{array}{c}12.43 \\
(8.9-16.2)\end{array}$ \\
\hline $32-40$ & $\begin{array}{c}18.60 \\
(4.3-48.2)\end{array}$ & $\begin{array}{c}16.70 \\
(8.3-40.3)\end{array}$ & $\begin{array}{c}15.30 \\
(5.0-33.6)\end{array}$ & $\begin{array}{c}13.27 \\
(5.2-31.9)\end{array}$ & $\begin{array}{c}15.70 \\
(5.5-33.8)\end{array}$ & $\begin{array}{c}16.66 \\
(4.6-36.6)\end{array}$ & $\begin{array}{c}9.23 \\
(5.4-13.3)\end{array}$ & $\begin{array}{c}10.33 \\
(6.2-13.4)\end{array}$ & $\begin{array}{c}9.96 \\
(6.2-13.3)\end{array}$ \\
\hline $40-51$ & $\begin{array}{c}23.25 \\
(4.6-64.1)\end{array}$ & $\begin{array}{c}20.57 \\
(7.6-51.5)\end{array}$ & $\begin{array}{c}15.85 \\
(4.7-36.4)\end{array}$ & $\begin{array}{c}13.67 \\
(4.7-34.2)\end{array}$ & $\begin{array}{c}19.92 \\
(5.5-46.8)\end{array}$ & $\begin{array}{c}20.02 \\
(4.5-46.5)\end{array}$ & $\begin{array}{c}8.00 \\
(5.4-11.0)\end{array}$ & $\begin{array}{c}8.80 \\
(5.7-10.6)\end{array}$ & $\begin{array}{c}8.30 \\
(4.4-10.9)\end{array}$ \\
\hline $51-64$ & $\begin{array}{c}22.20 \\
(4.7-66.1)\end{array}$ & $\begin{array}{c}20.47 \\
(7.9-53.2)\end{array}$ & $\begin{array}{c}12.70 \\
(4.3-28.7)\end{array}$ & $\begin{array}{c}11.27 \\
(3.7-27.6)\end{array}$ & $\begin{array}{c}19.45 \\
(5.2-46.8)\end{array}$ & $\begin{array}{c}18.90 \\
(4.4-45.1)\end{array}$ & $\begin{array}{c}7.80 \\
(5.4-10.9)\end{array}$ & $\begin{array}{c}8.23 \\
(5.2-10.5)\end{array}$ & $\begin{array}{c}8.07 \\
(4.1-10.1)\end{array}$ \\
\hline $64-81$ & $\begin{array}{c}16.03 \\
(4.9-45.2)\end{array}$ & $\begin{array}{c}15.47 \\
(6.5-36.2)\end{array}$ & $\begin{array}{c}8.35 \\
(3.8-16.3)\end{array}$ & $\begin{array}{c}7.22 \\
(3.0-15.0)\end{array}$ & $\begin{array}{c}14.50 \\
(6.1-29.8)\end{array}$ & $\begin{array}{c}13.87 \\
(6.5-30.0)\end{array}$ & $\begin{array}{c}9.10 \\
(6.5-11.1)\end{array}$ & $\begin{array}{c}8.20 \\
(5.6-11.8)\end{array}$ & $\begin{array}{c}8.97 \\
(6.1-11.0)\end{array}$ \\
\hline $81-102$ & $\begin{array}{c}10.35 \\
(4.4-22.4)\end{array}$ & $\begin{array}{c}11.35 \\
(5.6-19.1)\end{array}$ & $\begin{array}{c}4.85 \\
(2.5-6.8)\end{array}$ & $\begin{array}{c}4.82 \\
(2.4-6.8)\end{array}$ & $\begin{array}{c}8.90 \\
(4.9-14.1)\end{array}$ & $\begin{array}{c}8.72 \\
(6.4-14.6)\end{array}$ & $\begin{array}{c}13.10 \\
(9.4-16.6)\end{array}$ & $\begin{array}{c}13.56 \\
(8.6-18.7)\end{array}$ & $\begin{array}{c}12.46 \\
(10.2-14.2)\end{array}$ \\
\hline $102-128$ & $\begin{array}{c}5.22 \\
(2.2-9.5)\end{array}$ & $\begin{array}{c}6.15 \\
(2.4-10.0)\end{array}$ & $\begin{array}{c}2.25 \\
(1.0-3.5)\end{array}$ & $\begin{array}{c}2.22 \\
(1.0-3.6)\end{array}$ & $\begin{array}{c}4.48 \\
(2.7-6.5)\end{array}$ & $\begin{array}{c}4.22 \\
(2.9-6.2)\end{array}$ & $\begin{array}{c}8.00 \\
(6.1-11.0)\end{array}$ & $\begin{array}{c}9.10 \\
(7.1-12.2)\end{array}$ & $\begin{array}{c}7.66 \\
(5.0-10.1)\end{array}$ \\
\hline $128-161$ & $\begin{array}{c}3.45 \\
(1.1-8.2)\end{array}$ & $\begin{array}{c}4.72 \\
(1.4-11.0)\end{array}$ & $\begin{array}{c}1.47 \\
(0.4-3.7)\end{array}$ & $\begin{array}{c}1.55 \\
(0.4-4.2)\end{array}$ & $\begin{array}{c}2.37 \\
(1.2-5.3)\end{array}$ & $\begin{array}{c}2.42 \\
(1.4-4.6)\end{array}$ & $\begin{array}{c}5.20 \\
(3.9-7.0)\end{array}$ & $\begin{array}{c}5.20 \\
(3.5-8.0)\end{array}$ & $\begin{array}{c}5.03 \\
(3.9-5.7)\end{array}$ \\
\hline $161-203$ & $\begin{array}{c}1.82 \\
(0.3-4.9)\end{array}$ & $\begin{array}{c}1.92 \\
(0.7-5.1)\end{array}$ & $\begin{array}{c}0.60 \\
(0.2-1.4)\end{array}$ & $\begin{array}{c}0.85 \\
(0.3-2.4)\end{array}$ & $\begin{array}{c}0.82 \\
(0.5-1.4)\end{array}$ & $\begin{array}{c}0.95 \\
(0.6-1.5)\end{array}$ & $\begin{array}{c}5.17 \\
(4.6-5.5)\end{array}$ & $\begin{array}{c}5.27 \\
(4.2-6.3)\end{array}$ & $\begin{array}{c}5.03 \\
(3.9-6.1)\end{array}$ \\
\hline $203-256$ & $\begin{array}{c}0.32 \\
(0.1-0.8)\end{array}$ & $\begin{array}{c}0.38 \\
(0.1-0.8)\end{array}$ & $\begin{array}{c}0.08 \\
(0.04-0.1)\end{array}$ & $\begin{array}{c}0.09 \\
(0.03-0.2)\end{array}$ & $\begin{array}{c}0.13 \\
(0.1-0.15)\end{array}$ & $\begin{array}{c}0.14 \\
(0.1-0.2)\end{array}$ & $\begin{array}{c}1.96 \\
(1.2-2.6)\end{array}$ & $\begin{array}{c}2.10 \\
(1.3-2.6)\end{array}$ & $\begin{array}{c}1.90 \\
(1.7-2.3)\end{array}$ \\
\hline $256-323$ & $\begin{array}{c}0.07 \\
(0.02-0.11)\end{array}$ & $\begin{array}{c}0.07 \\
(0.0-0.1)\end{array}$ & $\begin{array}{c}0.02 \\
(0.01-0.03)\end{array}$ & $\begin{array}{c}0.02 \\
(0.0-0.04)\end{array}$ & $\begin{array}{c}0.02 \\
(0.01-0.04)\end{array}$ & $\begin{array}{c}0.04 \\
(0.02-0.06)\end{array}$ & $\begin{array}{c}0.67 \\
(0.1-1.3)\end{array}$ & $\begin{array}{c}0.63 \\
(0.06-1.0)\end{array}$ & $\begin{array}{c}0.74 \\
(0.1-1.1)\end{array}$ \\
\hline $323-406$ & $\begin{array}{c}0.02 \\
(0.0-0.05)\end{array}$ & $\begin{array}{c}0.01 \\
(0.0-0.3)\end{array}$ & $\begin{array}{c}0.01 \\
(0.0-0.01)\end{array}$ & $\begin{array}{c}0.01 \\
(0.0-0.01)\end{array}$ & $\begin{array}{c}0.01 \\
(0.0-0.01)\end{array}$ & $\begin{array}{c}0.01 \\
(0.0-0.01)\end{array}$ & $\begin{array}{c}0.07 \\
(0.01-0.15)\end{array}$ & $\begin{array}{c}0.08 \\
(0.01-0.18)\end{array}$ & $\begin{array}{c}0.07 \\
(0.03-0.12)\end{array}$ \\
\hline Total & $\begin{array}{c}118.53 \\
(54.9-300.9)\end{array}$ & $\begin{array}{c}114.76 \\
(54.6-253.7)\end{array}$ & $\begin{array}{c}77.03 \\
(36.4-156.9)\end{array}$ & $\begin{array}{c}68.81 \\
(27.3-150.0)\end{array}$ & $\begin{array}{c}101.00 \\
(50.2-207.0)\end{array}$ & $\begin{array}{c}101.72 \\
(43.5-214.6)\end{array}$ & $\begin{array}{c}79.37 \\
(54.9-105.9)\end{array}$ & $\begin{array}{c}83.37 \\
(55.0-108.9)\end{array}$ & $\begin{array}{c}80.62 \\
(57.3-93.4)\end{array}$ \\
\hline Larval capelin & & & & & & & & & \\
\hline Growth & - & 0.20 & 0.18 & 0.25 & 0.25 & 0.24 & 0.13 & $\begin{array}{c}0.16 \\
29\end{array}$ & 0.18 \\
\hline $\mathrm{n}$ & 0 & 1 & 6 & 18 & 20 & 6 & 15 & 29 & 31 \\
\hline Mortality & 1.25 & - & 3.59 & 1.91 & 2.38 & 1.82 & 10.20 & 4.66 & 9.15 \\
\hline $\mathrm{n}$ & 119 & 0 & 308 & 176 & 214 & 169 & 417 & 371 & 493 \\
\hline
\end{tabular}

Fig. 4. (A) Relation between growth ( $\mathrm{mm} \mathrm{d}^{-1}$ ) of capelin larvae and the concentration (no. $1^{-1}$ ) of prey particles 40 to $51 \mu \mathrm{m}$ (esd). Experiment and enclosure number are shown next to each data point. (B) Correlation coefficients ( $\mathrm{r}$ ) between growth of capelin larvae and concentration of potential prey in 6 size classes

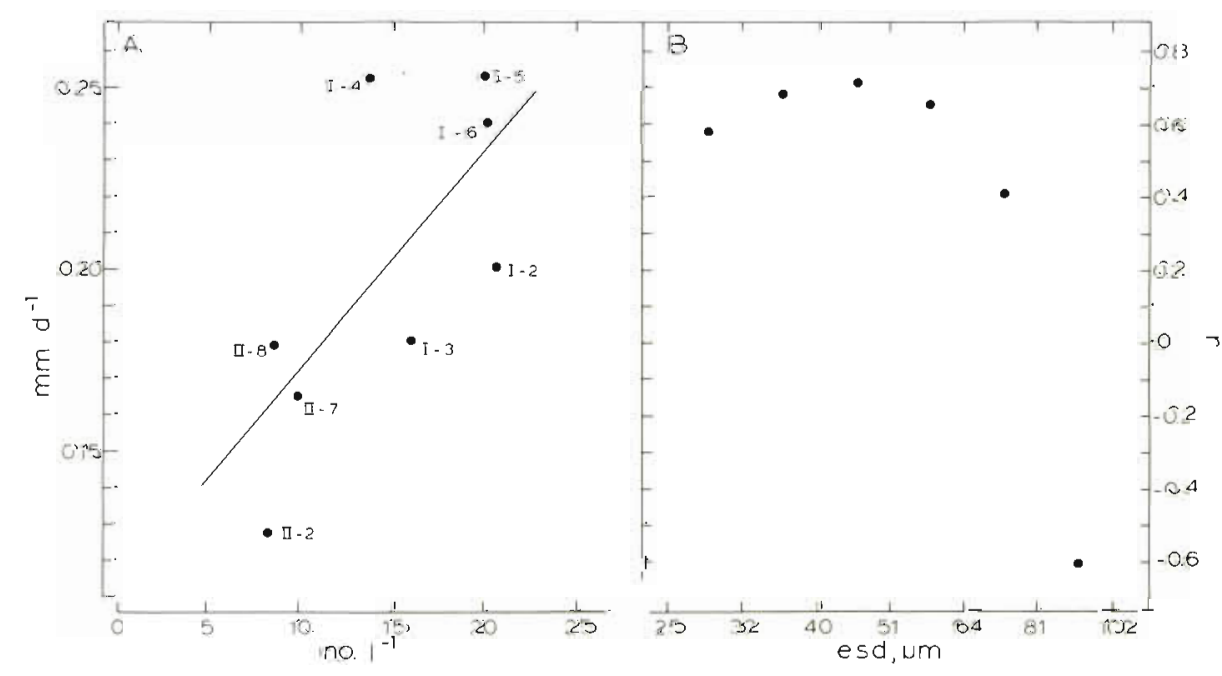




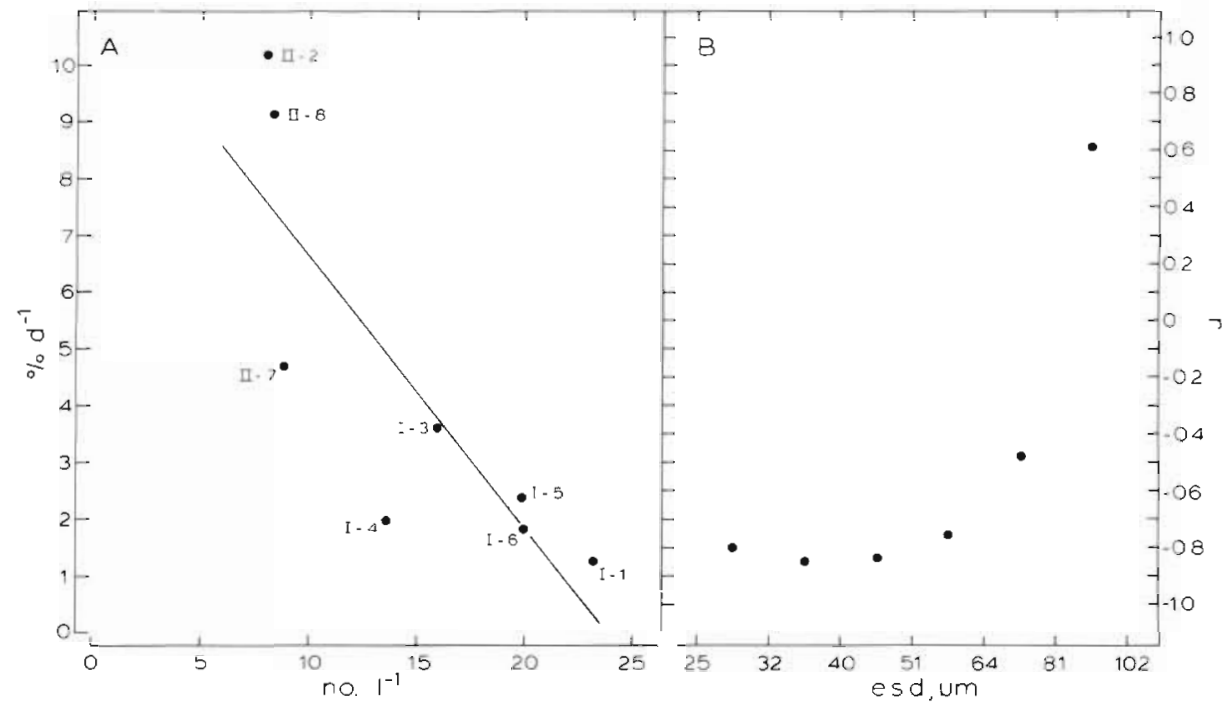

Fig. 5. (A) Relation between daily mortality $(\%)$ of larval capelin and concentration of prey particles (no. $\mathrm{l}^{-1}$ ) 40 to $51 \mu \mathrm{m}$ (esd). Next to each data point is the experiment and enclosure number. (B) Correlation coefficients ( $\mathrm{r}$ ) between daily mortality and concentration of potential prey in 6 size classes cles $\mathrm{l}^{-1}$; Leggett 1986). Growth rates of larvae in both experiments exhibited no systematic relation with the total quantity of plankton to which they were exposed $(r=0.29, P>0.05)$. However, both the average growth rate and the range of growth rates of larvae reared in Experiment I were higher than those of larvae reared in Experiment II. These differences were both significant and substantial, and were directly related to differences in the quantity of plankton $<81 \mu \mathrm{m}$ and specifically to the concentration of prey in the 40 to $51 \mu \mathrm{m}$ size range $(\mathrm{r}=0.72, \mathrm{P}<0.05)$. In Experiment $\mathrm{I}$, the absolute and relative abundance of plankton in the optimal 40 to $51 \mu \mathrm{m}$ size range was significantly greater than that prevailing during Experiment II (Table 2).

Within either Experiment I or II only a weak correlation $(\mathrm{P}>0.05)$ was observed between prey density and growth rate of capelin larvae. In Experiment I this may have been due, in part, to the non-limiting levels of prey density among enclosures. Both experiments had low recovery rates of larvae $(n \leq 20)$, presumably due to the avoidance of the collecting net by capelin larvae. This resulted in growth rate estimates that probably should be considered as a first approximation.

The potential prey size of first-feeding capelin larvae, calculated from mouth width measurements (Taggart 1986) and diet analyses of other species showing that the average width of prey ranges between 13 and $38 \%$ of the mouth width (reviewed by Theilacker \& Dorsey 1980), was between 29 and $86 \mu \mathrm{m}$. This result strengthens our suggestion that the 40 to $51 \mu \mathrm{m}$ esd interval may be an optimum size range of prey for capelin larvae. The few studies that have reported on the diet composition of first-feeding capelin larvae show the frequent occurrence of unidentified flagellates 40 to $50 \mu \mathrm{m}$ (width) in the guts of larvae reared in concrete basins in Norway (Moksness 1982) and the diatom Coscinodiscus sp. and the ciliate Tin- tinnopsis sp. as the principle food source of larvae in the St. Lawrence estuary (Courtois \& Dodson 1986). In our nearshore collections during summer in Bryant's Cove the most abundant planktonic forms were tintinnids, diatoms, and copepod eggs and nauplii. Quantitative plankton studies conducted in a nearby embayment in Conception Bay during summer revealed the presence of large quantities of tintinnids $\left(>100 \mathrm{l}^{-1}\right.$ ) confined to the surface water mass (Davis 1982).

The size structure of the plankton complex to which the larvae were exposed during Experiment I was typical of the plankton community that dominates the nearshore area of Newfoundland during onshore winds. This is the community with which the larvae of capelin become associated by virtue of synchronous, active emergence from the beach nursery sites in response to temperature or other signals indicative of its presence in the nearshore area (Frank \& Leggett $1983 b)$. This selective occupation of the surface water mass, in contrast to a strategy of continuous emergence at hatching which would cause most larvae to become associated with plankton communities having a size structure similar to that recreated in Experiment II, yields an average increase in growth of approximately $30 \% \mathrm{~d}^{-1}$

The growth rates achieved by larvae in Experiment I (mean $0.23 \mathrm{~mm} \mathrm{~d}^{-1}$, range 0.18 to 0.25 ), in which the size structure and the range of biomass of the plankton most closely reflected that occurring in surface waters around Newfoundland, were very similar to those reported for larvae in the Gulf of St. Lawrence over a 6 mo period (mean $0.25 \mathrm{~mm} \mathrm{~d}^{-1}$, range 0.20 to 0.35 ; Jacquaz et al. 1977). Here, larvae drift with the seaward-flowing surface water layer and maintain themselves in the upper $20 \mathrm{~m}$ of the water column during the first 2 to 4 mo after hatching (Jacquaz et al. 1977 , Fortier \& Leggett 1984, 1985). 
Further evidence that the growth rates exhibited by larvae in Experiment I closely reflect those experienced by larvae occupying the surface water mass in situ is given by an analysis of the length distributions of larvae collected from the surface waters of the northern Grand Banks from 1 to 20 September 1978 (Poletayev 1979). In 1978, significant onshore winds occurred 4 times (Fig. 6A) in the period during which larval capelin were hatching and abundant on the capelin spawning beaches of eastern Newfoundland (Frank \& Leggett 1981; see their Fig. 2). This wind pattern would result in the synchronous release of 4 distinct 'cohorts' of capelin larvae over at least $700 \mathrm{~km}$ of Newfoundland's east coast on approximately July 2, 14, 22 and August 2. The length frequency distribution of capelin larvae from the northern Grand Banks revealed 4 distinct peaks (Fig. 6B). Assuming an average larval length at emergence of $5 \mathrm{~mm}$ (Frank \& Leggett 1982a) and drift periods of $72,58,50$ and $39 \mathrm{~d}$ for cohorts emerging on July 2, 14, 22 and August 2 respectively, it is possible to calculate the growth rates achieved by members of each cohort based on their mean size on September 10. These rates were 0.25 , $0.26,0.26$, and $0.26 \mathrm{~mm} \mathrm{~d}^{-1}$ respectively. The close correspondence between these estimates and the growth rates derived from Experiment I (Table 2) serves to increase our confidence in the reliability of the limited data used to calculate growth rates of larval capelin from the enclosures.

\section{Mortality}

The differences in daily mortality rates recorded during Experiments I and II and the strong relation between mortality rate and the concentration of prey in the $<81 \mu \mathrm{m}$ (esd) size classes also underscores the importance of prey size distribution to survival. As previously noted, the range of total concentrations of plankton was similar between experiments. However, larvae reared in Experiment II, which were exposed to plankton characteristic of the deep upwelling water mass which dominates the nearshore areas during the prevailing offshore winds, experienced mortality rates which were as much as 3-fold greater than those experienced in Experiment I. The major difference in experimental conditions between experiments was the source of the plankton prey provided. For Experiment I, all but the last prey collection occurred during onshore winds. On these occasions the plankton community of the cove was characterized by having higher concentrations of plankton in the smaller $(<80 \mu \mathrm{m})$ edible size classes (Fig. 1 \& 2). Capelin larvae were of similar size (range of average total length: 4.5 to $4.7 \mathrm{~mm}$ ), possessed full yolk sacs, and were in good physical condition (according to the classification scheme of Frank \& Leggett 1982a) at the beginning of each experiment.

The data contained in Fig. 5b suggest that, in situ, the existence of a relation between mortality rate and prey abundance may be determined not by the absolute abundance of plankton, but by its size distribution. The combined data on growth and mortality rates in relation to prey size and abundance suggest that larvae may be significantly food-limited even when total prey concentrations exceed estimates of the critical minimum values by 10 to 50 times, if the particle size composition is inappropriate. These observations may explain, in part, the conflicting information now available on the relation between prey abundance and larval survival in marine fishes.

The maximum daily mortality rates observed in these experiments (ca $10 \% \mathrm{~d}^{-1}$ ) were significantly lower than estimates for capelin larvae of similar ages at liberty in the nearshore waters of Bryant's Cove (Taggart 1986: 55 to $65 \% \mathrm{~d}^{-1}$ ) and in the St. Lawrence estuary (Fortier \& Leggett 1985: $56 \% \mathrm{~d}^{-1}$ ). One of the major differences in the conditions experienced by larvae in our enclosures was the absence of predators. Fortier \& Leggett (1985) and Taggart (1986) determined dispersion-corrected mortality rates for individual cohorts of larvae within discrete water masses. Their estimates are not, therefore, subject to the aliasing that has frequently biased predator/prey analyses related to larval fish mortality (Frank \& Leggett 1985). The significant difference between these estimates suggests that predation may be an important regulator of mortality within discrete cohorts of larvae. The very low mortality fish larvae experience in mesocosms given adequate food resources but lacking predators has been previously documented (Laurence et al. 1979, $\varnothing$ iestad 1985). Isolating the water column by enclosing it from the surrounding waters may also reduce vertical mixing (Steele et al. 1977) and serve to improve the foraging success of larvae.

On a broader time scale, the basis for the evolution of larval behaviour which results in the selective occupation of particular water masses (Frank \& Leggett 1983a, b), current regimes (Arthur 1977, Fortier \& Leggett 1983, 1985) and retention zones (Jacquaz et al. 1977 , Sinclair \& Iles 1985) is clarified to some degree by the results of these experiments. Our data suggest that if larvae are to survive in large numbers they must become associated with waters not only rich in plankton, but rich in plankton of the appropriate size. This reality has been obvious and widely accepted for some time (see Ware 1977). However, the magnitude and form of the mortality function experienced by larvae who failed to do so, and the nature of the interacting effects of food abundance and size composition on that function, has not previously been defined. 


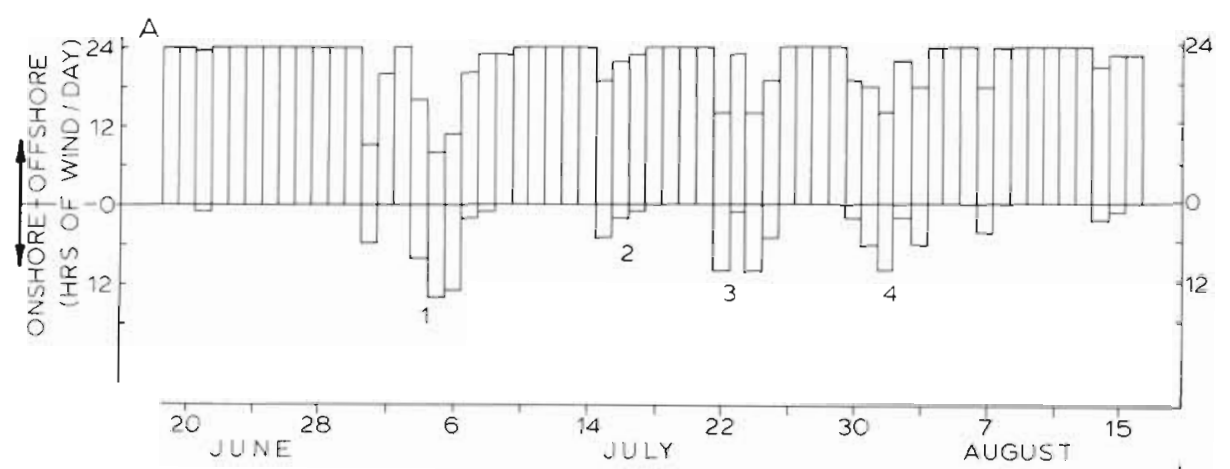

Fig. 6. (A) Daily occurrence of offshore (SE to NW) and onshore (N to E) wind during Jun to Aug 1978 taken from Atmospheric Environment Service, Canada, wind monitoring installation at Holyrood, Newfoundland (approximately $40 \mathrm{~km}$ SSE of Bryant's Cove). (B) Length frequency dis-

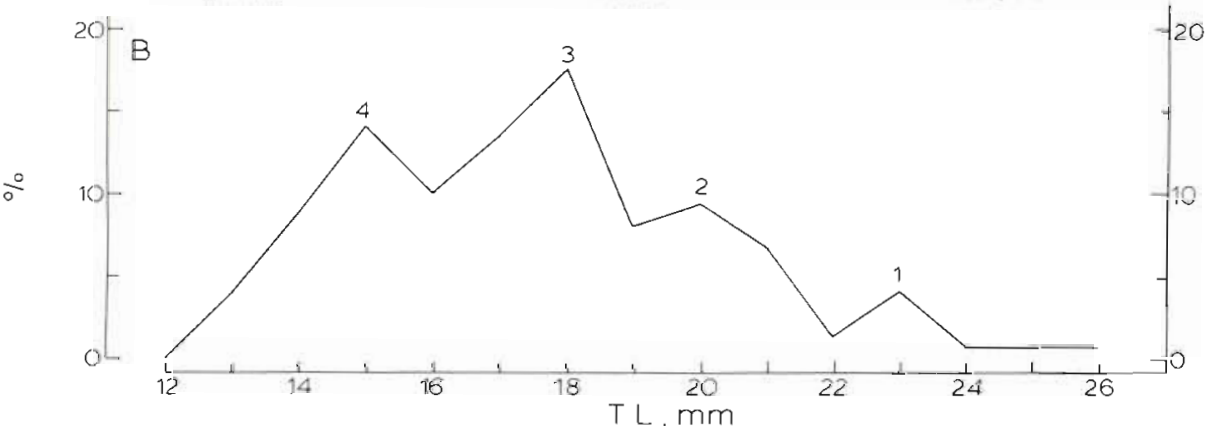
tribution of larval capelin ( $\mathrm{n}=$ 148) taken from Poletayev's (1979) study of capelin larvae in the offshore waters of eastern Newfoundland. Numbers 1 to 4 show occurrence of wind events causing the dispersal of larval capelin from the beaches of eastern Newfoundland and the length mode of the resultant cohort in panels $A$. and $B$ respectively

The significant dependence of larval growth and survival on the size distribution of the plankton also has interesting implications for year-to-year variability in overall larval survival and recruitment. Inter-annual variability in the temperature/salinity characteristics of local water masses could result in significant changes in the particle size spectra of plankton communities to which the larvae are exposed. Both Deevey (1960) and Ware (1977) have documented inverse relations between water temperature and the mean size of marine zooplankton. Our data on changes in plankton community size spectra, in concert with changes in the origin of nearshore water masses, are consistent with these findings. In this connection, it is noteworthy that inter-annual variability in the year-class strength of NAFO Division $2 \mathrm{~J} 3 \mathrm{~K}$ capelin is positively correlated with water temperatures $\left(r^{2}=0.43\right)$ in the 0 to $20 \mathrm{~m}$ depth interval during the July to December period of larval drift, and that the July to August temperatures are most important in establishing this relation (Leggett et al. 1984). We had speculated that total plankton production was positively correlated with water temperature, thereby promoting the formation of strong year-classes during relatively warm years. An additional effect, suggested by the results of this study, is that cold years cause a shift in the particle size spectrum of microzooplankton in the surface waters occupied by larval capelin towards larger sizes thereby inducing slower growth and poorer survival.

The direct effect of growth on survival remains obscure. Several investigators have suggested that increased growth rates may convey a survival advan- tage by reducing the length of the period during which larvae are most susceptible to predation (see Jones 1973, Ware 1975). Conversely, the length of the larval period (time to metamorphosis) may be inversely proportional to growth rate. If so, during years in which conditions favour rapid growth, the duration of the larval period, when mortality rates are maximal, could be significantly shortened thereby leading to an important reduction in total mortality to the larval year-class. This possibility is now under investigation.

Acknowledgements. Financial support for this research was provided by the Natural Sciences and Engineering Research Council of Canada and by Fisheries and Oceans Canada, Science Subvention Program. Logistic and other assistance was provided by Fisheries and Oceans Canada, Fisheries Research Branch, St. John's, Newfoundland. We are particularly indebted to Dr. J. E. Carscadden for his assistance. Mrs Kathleen Frank and Messrs Mike Dolan and Frances Juanes provided valuable technical assistance in the field and laboratory. Mrs Lorraine Allen contributed to the preparation of the manuscript. Finally, we thank the residents and fishermen of Bryant's Cove, Newfoundland. Their hospitality and their willingness to assist under any conditions contributed greatly to the success of our work.

\section{LITERATURE CITED}

Arthur, D. K. (1977). Distribution, size and abundance of microcopepods in the California current system and their possible influence on survival of marine teleost larvae. Fish. Bull. U.S. 75 (3): 601-611

Bailey, K. M. (1981). Larval transport and recruitment of Pacific hake Merluccius productus. Mar. Ecol. Prog. Ser. 6: $1-9$ 
Beers, J. R., Stewart, G. L. (1967). Micro-zooplankton in the euphotic zone at five locations across the California current. J. Fish. Res. Bd Can. 24 (10): 2053-2068

Corlett, J. (1958). Distribution of larval cod in the western Barents Sea. Spec. Publs. int. Comm. N.W. Atlant. Fish. 1: 181-188

Courtois, R., Dodson, J. J. (1986). Régime alimentaire et principaux facteurs influencant l'alimentation des larves de capelan (Mallotus villosus), d'éperlan (Osmerus mor$d a x$ ) et de hareng (Clupea harengus harengus), dans un estuaire partiellement mélangé. Can. J. Fish. Aquat. Sci 43: $968-979$

Davis, C. C. (1982). A preliminary quantitative study of the zooplankton from Conception Bay, Insular Newfoundland, Canada. Int. Revue ges. Hydrobiol. 67: 713-747

Deevey, G. B. (1960). Relative effects of temperature and food on seasonal variations in length of marine copepods. Bull. Bingham. oceanogr. Coll. 17: 54-86

Dekhnik, T. V., Sinyvkova, V. I. (1976). Survival of marine fish larvae in relation to food availability. J. Ichthyol. 16: 294-302

Fortier, L., Leggett, W. C. (1983). Vertical migration and transport of larval fish in a partially mixed estuary. Can. J Fish. Aquat. Sci. 40: 1543-1555

Fortier, L., Leggett, W. C. (1984). Small-scale covariability in the abundance of fish larvae and their prey. Can. J. Fish Aquat. Sci. 41: 502-512

Fortier, L., Leggett, W. C. (1985). A drift study of larval fish survival, Mar. Ecol. Prog. Ser. 25: 245-257

Frank, K. T., Leggett, W. C. (1981). Wind regulation of emergence times and early larval survival in capelin (Mallotus villosus). Can. J. Fish. Aquat. Sci. 38: 215-223

Frank, K. T., Leggett, W. C. (1982a). Environmental regulation of growth rate, efficiency, and swimming performance in larval capelin (Mallotus villosus), and its application to the match-mismatch hypothesis. Can. J. Fish. Aquat. Sci. 39: 691-699

Frank, K. T., Leggett, W. C. (1982b). Coastal water mass replacement: its effect on zooplankton dynamics and the predator-prey complex associated with larval capelin (Mallotus villosus). Can. J. Fish. Aquat. Sci. 39 (7): 991-1003

Frank, K. T., Leggett, W. C. (1983a). Multispecies larval fish associations: accident or adaptation? Can. J. Fish. Aquat. Sci. 40: 754-762

Frank, K. T., Leggett, W. C. (1983b). Survival value of an opportunistic life stage transition in capelin (Mallotus villosus). Can. J. Fish. Aquat. Sci. 40: 1442-1448

Frank, K. T., Leggett, W. C. (1985). Reciprocal oscillations in densities of larval fish and potential predators: a reflection of present or past predation? Can. J. Fish. Aquat. Sci. 42: 1841-1849

Govoni, J. J., Chester, A. J., Hoss, D. E., Ortern, P. B. (1985). An observation of episodic feeding and growth of larval Leiostomus xanthurus in the northern Gulf of Mexico. J. Plankton Res. 7: 137-146

Greve, W., Parsons, T. R. (1977). Photosynthesis and fish production: hypothetical effects of climatic change and pollution. Helgoländer wiss. Meeresunters. 30: 666-672

Houde, E. C. (1975). Effects of stocking density and food density on survival, growth and yield of laboratory-reared larvae of sea bream Archosargus rhomboidalis (L) (Sparidae). J. Fish Biol. 7: 115-127

Hunter, J. R. (1981). Feeding ecology and predation of marine fish larvae. In: Lasker, R. (ed.) Marine fish larvae. Morphology, ecology and relation to fisheries. Univ. Washington Press, Seattle, p. 33-77
Jacquaz, B., Able, K. W., Leggett, W. C. (1977). Seasonal distribution, abundance, and growth of larval capelin (Mallotus villosus) in St. Lawrence estuary and northwestern Gulf of St. Lawrence. J. Fish. Res. Bd Can. 34: 2015-2029

Jones, R. (1973). Density dependent regulation of numbers of cod and haddock. Rapp. P.-v. Réun. Cons. int. Explor. Mer 64: $56-173$

Landry, M. R. (1977). A review of important concepts in the trophic organization of pelagic ecosystems. Helgoländer wiss. Meeresunters. 30: 8-17

Lasker, R. (1975). Field criteria for survival of anchovy larvae: the relation between inshore chlorophyll maximum layers and successful first feeding. Fish. Bull. U.S. 73: 212-230

Lasker, R. (1978). The relation between oceanographic conditions and larval anchovy food in the California Current: identification of factors contributing to recruitment failure, Rapp. P.-v, Réun. Cons. int. Explor. Mer 173: 212-230

Lasker, R., Feder, H. M., Theilacker, G. H., May, R. C. (1970). Feeding, growth, and survival of Engraulis mordax larvae reared in the laboratory. Mar. Biol. 5: 345-353

Lasker, R., Zweifel, J. R. (1978). Growth and survival of firstfeeding anchovy larvae (Engraulis mordax) in patches containing different proportions of large and small prey. In: Steele, J. H. (ed.) Spatial pattern in plankton communities, Plenum Press, New York, p. 329-354

Laurence, G. C., Halavik, T A., Burns, B. R., Smigielski, A. S. (1979). An environmental chamber for monitoring in situ growth and survival of larval fishes. Trans. Am. Fish. Soc. 108: $197-203$

Leggett, W. C. (1986). The dependence of fish larval survival on food and predator densities. In: Skreslet, S. (ed.) NATO ASI Series, Vol. G7. The role of freshwater outflow on coastal marine ecosystems. Springer, Berlin, Heidelberg, p. $117-127$

Leggett, W. C., Frank, K. T., Carscadden, J. E. (1984). Meteorological and hydrographic regulation of year-class strength in capelin (Mallotus villosus). Can. J. Fish. Aquat. Sci. 41: 1193-1201

Lough, R. G. (1984). Larval fish trophodynamic studies on Georges Bank: sampling strategy and initial results. In: Dahl, E., Danielssen, D. S., Moksness, E., Solemdal, P. (ed.) The propagation of cod Gadus morhua L. Flødevigen rapportser 1: 395-434

May, R. C. (1974). Larval mortality in marine fishes and the critical period concept. In: Blaxter, J. H. S. (ed.) The early life history of fish. Springer, New York, p. 3-19

Moksness, E. (1982). Food uptake, growth and survival of capelin larvae (Mallotus villosus Muller) in an outdoor constructed basin. FiskDir. Skr. Ser. Havunders. 17: $267-285$

Nelson, W. R., Ingham, M. C., Schaff, W. E. (1977). Larval transport and year class strength of Atlantic menhaden, Brevoortia tyrannus. Fish. Bull. U.S. 75: 23-42

O'Boyle, R. N., Sinclair, M., Conover, R. J., Mann, K. H., Kohler, A. C. (1984). Temporal and spatial distribution of ichthyoplankton communities of the Scotian Shelf in relation to biological, hydrological, and physiographic features. Rapp. P.-v, Réun. Cons. int. Explor. Mer 183: $27-40$

Ciestad, V. (1985). Predation on fish larvae as a regulatory force, illustrated in mesocosm studies with large groups of larvae. NAFO Sci. Coun. Studies 8: 25-32

Owen, R. W. (1981). Microscale plankton patchiness in the larval anchovy environment. Rapp. P.-v. Réun. Cons. int. Explor. Mer 178: 364-368

Parsons, T. R., LeBrasseur, J. R. (1970). The availability of food 
to different trophic levels in the marine food chain. In: Steele, J. H. (ed.) Marine food chains. Plenum Publ. Corp. New York, p. 325-343

Poletayev, V. A. (1979). Investigations on larvae and prerecruits of capelin in the northwest Atlantic in September, 1978. Int. Comm. Northw. Atl. Fish. Res. Doc. 79/VI/105

Sinclair, M., Mes, T. D. (1985). Atlantic herring (Clupea harengus) distributions in the Gulf of Maine-Scotian Shelf area in relation to oceanographic features. Can. J. Fish. Aquat. Sci. 42: 880-887

Sinclair, M., Tremblay, J. J., Bernal, P. (1985). El Niño events and variability in a Pacific mackerel (Scomber japonicus) survival index: support for Hiort's second hypothesis. Can. J. Fish. Aquat. Sci. 42:602-608

Steele, J. H., McIntyre, A. D., Edwards, R. R. C., Trevallion, A. (1969). Interrelations of a young plaice population with its invertebrate food supply. In: Watson, A. (ed.) Animal populations in relation to their food resources. Blackwell Sci. Publ., Oxford, p. 375-388

Steele, J. H., Farmer, D. M., Henderson, E. W. (1977). Circulation and temperature structure in large marine enclosures. J. Fish. Res. Bd Can. 34: 1095-1104

Sysoeva, T. K., Degtereva, S. A. (1965). The relation between the feeding of cod larvae and pelagic fry and the distribution and abundance of their principal food organisms. Spec. Publs. Int. Comm. N.W. Atlant. Fish. 6: 411-416

Taggart, C. T. (1986). Mortality of larval capelin (Mallotus villosus Muller): environmental and density correlates during post-emergent dispersal. Ph.D. thesis, McGill University, Montreal
Taggart, C. T., Leggett, W. C. (1984). Efficiency of largevolume plankton pumps, and evaluation of a design suitable for deployment from small boats. Can. J. Fish. Aquat. Sci. 41: 1428-1435

Theilacker, G., Dorsey, K. (1980). Larval fish diversity, a summary of laboratory and field research. In: Sharp, G. (rapporteur) Workshop on the effects of environmental variation on the survival of larval pelagic fishes. UNESCO, Intergovernmental Oceanographic Commission, Workshop Report 28, p. 105-142

Tilseth, S., Ellertsen, B. (1984). The detection and distribution of larval Arcto-Norwegian cod, Gadus morhua, food organisms by an in situ particle counter. Fish. Bull. U.S. 82: $141-156$

Tremblay, M. J., Roff, J. C. (1983). Community gradients in the Scotian Shelf zooplankton. Can. J. Fish. Aquat. Sci. 40: 598-611

Ware, D. M. (1975). Relation between egg size, growth and natural mortality of larval fish. J. Fish. Res. Bd Can. 32: 2503-2512

Ware, D. M. (1977). Spawning time and egg size of Atlantic mackerel, Scomber scombrus, in relation to the plankton. J. Fish. Res. Bd Can. 34: 2308-2315

Werner, R. G., Blaxter, J. H. S. (1981). The effect of prey density on mortality, growth and food consumption in larval herring (Clupea harengus L.). Rapp. P.-v. Réun. Cons. int. Explor. Mer 178: 405-408

Wyatt, T. (1972). Some effects of food density on the growth and behavior of plaice larvae. Mar. Biol. 14: 210-216

This article was presented by Dr. K. Sherman; it was accepted for printing on August 25, 1986 